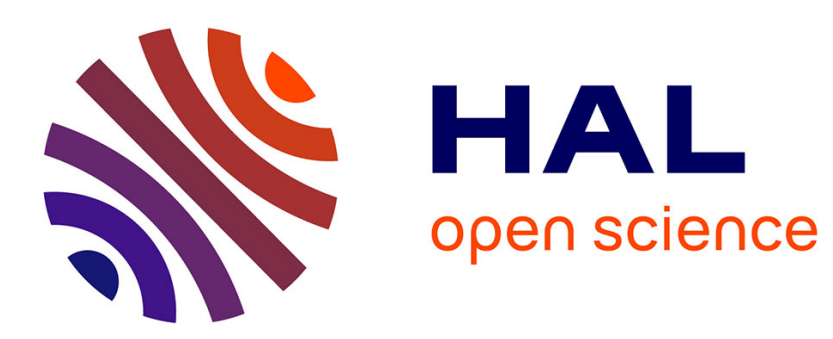

\title{
A new competitive fluorescence immunoassay for detection of Listeria monocytogenes
}

Beauchamp Stéphane, d'Auria Sabato, Pennacchio Anna, Lacroix Monique

\section{To cite this version:}

Beauchamp Stéphane, d'Auria Sabato, Pennacchio Anna, Lacroix Monique. A new competitive fluorescence immunoassay for detection of Listeria monocytogenes. Analytical Methods, 2012, 4, pp.418792. 10.1039/C2AY25997D . pasteur-01002825

\section{HAL Id: pasteur-01002825 https://hal-riip.archives-ouvertes.fr/pasteur-01002825}

Submitted on 13 Aug 2014

HAL is a multi-disciplinary open access archive for the deposit and dissemination of scientific research documents, whether they are published or not. The documents may come from teaching and research institutions in France or abroad, or from public or private research centers.
L'archive ouverte pluridisciplinaire HAL, est destinée au dépôt et à la diffusion de documents scientifiques de niveau recherche, publiés ou non, émanant des établissements d'enseignement et de recherche français ou étrangers, des laboratoires publics ou privés. 


\title{
Analytical Methods
}

\section{A new competitive fluorescence immunoassay for detection of Listeria monocytogenes}

\author{
Stéphane Beauchamp, ${ }^{a}$ Sabato D’Auria, ${ }^{* b}$ Anna Pennacchio ${ }^{b}$ and Monique Lacroix ${ }^{a}$
}

Received 5th September 2012, Accepted 13th October 2012

DOI: $10.1039 / \mathrm{c} 2 \mathrm{ay} 25997 \mathrm{~d}$

\begin{abstract}
A new competitive immunoassay has been designed using a specific monoclonal antibody labeled with a fluorophore. A specific and highly conserved peptide of 11 amino acids from the protein p60 of $L$. monocytogenes has been synthesised and used for the production of a monoclonal anti-p60. This antibody was used in the conception of a detection test able to detect $1 \mathrm{CFU}$ of $L$. monocytogenes after only 18 hours of incubation with a minimum of manipulation. The test is based on a competition principle between the recombinant p60 protein and the p60 from L. monocytogenes present in the sample. A column containing a sepharose matrix was used to immobilize the recombinant p60 protein and the labeled monoclonal antibody, which is captured by the p60 from the sample when added to the column. An increase of the fluorescence signal of the eluate means a positive result. No cross-reactivity was observed with non-pathogenic Listeria species and each serotype of L. monocytogenes can be detected whereas some other immunological methods show cross-reactivity and false negative.
\end{abstract}

\section{Introduction}

Listeria monocytogenes is an important foodborne pathogen involved in several outbreaks around the world resulting in considerable economic and human losses. Its widespread presence in the environment and its persistence in food plants lead to a labored control of this microorganism. L. monocytogenes is a Gram-positive, rod-shaped facultative anaerobic bacterium. This microbe can grow in a wide range of temperatures $\left(1{ }^{\circ} \mathrm{C}\right.$ to $\left.45^{\circ} \mathrm{C}\right)$ between $\mathrm{pH} 4.6$ and 9.5 and at a water activity as low as $0.92 .{ }^{1} \mathrm{It}$ finds favorable growth conditions on floors, drains and equipment within food industry premises, notably in the cold and wet atmosphere of refrigerated rooms where only psychrotrophic bacteria can survive. ${ }^{2}$ In a review published in 2004, few studies are mentioned in which persistence of $L$. monocytogenes is demonstrated. ${ }^{3}$ Refrigerated and ready-to-eat foods constitute thereby a potential risk for contamination. ${ }^{4,5}$ To counter crosscontamination, the control of the environment by detecting the bacteria on the working surfaces and instruments could be an important tool. Several well-known outbreaks and food recalls due to $L$. monocytogenes ${ }^{6-9}$ combined with the high case-fatality rate of $20-30 \%$ (ref. 10) have increased the need for more rapid,

${ }^{a}$ Research Laboratories in Sciences Applied to Food, Canadian Irradiation Center, Institute of Nutraceutical and Functional Foods (INAF), INRS-Institut Armand-Frappier, 531 Boulevard des Prairies, Laval, Québec H7V 1B7, Canada

${ }^{b}$ Laboratory for Molecular Sensing, IBP-CNR, Via Pietro Castellino 111 80131 Naples, Italy. E-mail: s.dauria@ibp.cnr.it; Fax: +39-0816132277; Tel: $+39-0816132250$ sensitive, and specific methods for detection of this bacterium not only in food, but also in the working environment.

L. monocytogenes is a widespread microorganism that can be readily isolated from a number of sources, such as soil, water, meat, and vegetables. ${ }^{11,12}$ Thus, the bacterium can easily be introduced in the human food chain and it becomes difficult to avoid contamination. Many reliable and accurate culture methods and media have been already developed for the detection of L. monocytogenes. ${ }^{13,14}$ However, these methods remain laborious, time-consuming and involve complicated procedures. ${ }^{15-19}$ Some standard methods for the detection of L. monocytogenes can require up to 7 days to yield results, as they rely on the ability of microorganisms to multiply to visible colonies. ${ }^{13}$ Existing DNA detection based methods are also expensive.

To overcome the difficulty of recovering $L$. monocytogenes in the presence of non-pathogenic Listeria species and increase the sensitivity of the detection, several PCR-based methods have been developed. These PCR methods ${ }^{14,18-20}$ provide sensitive, specific, and reproducible detection of pathogenic bacteria. Despite showing valuable advantages, the fact remains that the limitations of applying PCR techniques cannot be disregarded. Among them, there is the presence of inhibitory substances, ${ }^{\mathbf{2 1 , 2 2}}$ complexity of matrices, sample preparation and DNA extraction procedures. ${ }^{14,23}$ Moreover, from an industrial point of view, routine detection of microbes using PCR can be expensive as it requires specialized equipment and qualified workers to carry out the tests. On the other hand, methods based on antigen-antibody bindings constitute a good alternative for detection of foodborne pathogens. The field of immunology-based methods provides very powerful analytical tools for a wide range of targets 
including bacterial cells, spores, viruses and toxins. ${ }^{24}$ Only for $L$. monocytogenes, few immunology-based methods already exist. ${ }^{25-34}$ Various antibody types and formats are available for immune-detection. These include conventional and heavy chain antibodies, as well as polyclonal, monoclonal or recombinant antibodies. While polyclonal antibodies are limited both in terms of their specificity and abundance, monoclonal antibodies are often more useful for specific detection because they provide an indefinite supply of single antibodies directed against a single and unique epitope. The progress of hybridoma techniques and the emergence of the recombinant antibody phage display technology have led to more sensitive, specific, reproducible and reliable immunological detection with many commercial immunoassays adapted for a variety of microbes and their products. $^{35}$

The protein p60 of L. monocytogenes, which is encoded by the iap (invasion-associated protein) gene, is considered an important virulence factor, although the exact role of the protein is not completely known. ${ }^{36,37}$ Mutants of L. monocytogenes, which impair synthesis of $\mathrm{p} 60$, show a rough-colony morphology ( $\mathrm{R}$ mutants) and are strikingly attenuated in virulence in mice. These mutants have also lost the capability of invading 3T6 mouse fibroblasts and form particularly long cell chains. Treatment of these mutants with partially purified p60 from wild-type $L$. monocytogenes restores their invasiveness and cell morphology.

The p60 protein could be a potential target for immunological detection because of its high abundance in the culture supernatant and high immunogenicity. ${ }^{31,38}$ Nevertheless, it has been shown that an antiserum raised against the whole p60 is not appropriate for specific detection of L. monocytogenes, since cross-reactivity occurred with p60-related proteins in the culture supernatant of all Listeria species. ${ }^{39}$ For this reason, the production of antibodies using p60 protein should be directed against an epitope, which is specific to L. monocytogenes. Many attempts have been made to produce Listeria-specific antibodies, but in most cases the potential was limited by the cross-reactivity with non-pathogen Listeria species or by the non-recognition of certain L. monocytogenes strains, which is not suitable for specific immunodetection. ${ }^{40}$ In a previous work, a short hydrophilic peptide of eleven amino acids (QQQTAPKAPTE) namely PepD has been identified within the p60 protein to be a highly conserved region specific to all $L$. monocytogenes strains. ${ }^{39}$ The polyclonal antibodies raised against this peptide showed a highly specific recognition for the p60 protein of all stains of L. monocytogenes tested and no cross-reactivity with non-pathogen Listeria spp. The results of this experiment allow us to consider this small peptide a good target for the development of an immunedetection test. However, due to the possible low titers of the polyclonal antibodies, a large amount of the precipitated protein was necessary to perform the analysis. Moreover, from a standpoint of a manufacturer producing a detection test using these antibodies, the repeated production of enough polyclonal antibodies may be demanding. Considering all of these limitations, the production of a monoclonal antibody using the same peptide of eleven amino acids specific to the p60 of L. monocytogenes was chosen. The aim of this study was to develop a competitive fluorescence immunoassay for the detection of $L$. monocytogenes using a p60 monoclonal antibody of $L$. monocytogenes.

\section{Material and methods}

\section{Synthetic peptide, monoclonal antibody and recombinant $\mathbf{P 6 0}$ production}

The peptide synthesis and the production of the anti-P60 monoclonal antibody were carried out by the company GenScript USA Inc., NJ, USA. First, the antigenic peptide PepD (QQQTAPKAPTE) derived from $\mathrm{p} 60$ of L. monocytogenes (accession number AEO02672 in the NCBI protein database) was synthesized by stepwise solid-phase peptide synthesis (SPPS) with an additional $\mathrm{N}$-terminal cysteine residue for coupling. ${ }^{38}$ Synthetic peptide was purified by reverse-phase HPLC and coupled via the SH group of the N-terminal cysteine residue to the keyhole limpet hemocyanin (KLH) carrier protein in order to stimulate the immune response. Five Balb/c mice were inoculated by intraperitoneal injection with $25-100 \mu \mathrm{g}$ of the conjugated peptide emulsified in the TiterMax adjuvant for primary immunization and boosted 3 times with $12.5-50 \mu \mathrm{g}$ of the conjugated peptide, also emulsified in the TiterMax adjuvant on days 14, 35 and 63. Cell fusion, subcloning of positive parental clones and expansion of positive subclones were screened using ELISA. Monoclonal antibodies from the hybridoma culture supernatant were purified using the protein A/G affinity column. ELISA and Western blot were performed to determine the purity, the concentration and the reactivity of the final antibody. Recombinant P60 protein has also been produced by Genscript. The pUC57 DNA plasmid was transformed into competent $E$. coli BL21 (DE3). The recombinant P60 protein was purified using the nickel column via polyhistidine-tag. Final protein concentration was found to be $0.531 \mathrm{mg} \mathrm{ml}^{-1}$ as determined by the Bradford protein assay with BSA as a standard. A purity of about $80 \%$ was estimated using Coomassie blue-stained sodium dodecyl sulphate-polyacrylamide gel electrophoresis (SDSPAGE).

\section{Bacterial strains and growth conditions}

Several strains of Listeria were used in this experiment: $L$. monocytogenes 2812, L. monocytogenes 1043 and L. monocytogenes 2569 (serotypes 1/2a), L. monocytogenes 2558, L. monocytogenes 2739 and L. monocytogenes 2371 (serotypes $1 / 2 \mathrm{~b}$ ), L. innocua LSPQ 3285 (purchased from Laboratoire de Santé Publique du Québec, Ste-Anne-de-Bellevue, Québec, Canada). $1 \mathrm{ml}$ of the fresh culture of all the strains were subcultured in $9 \mathrm{ml}$ of Tryptic Soy Broth (TSB, Difco Laboratory, Detroit, MI) at $37{ }^{\circ} \mathrm{C}$ under stirring. Culture supernatants were collected after centrifugation at $5500 \mathrm{rpm}$ for 10 minutes followed by filtration using a $0.25 \mu \mathrm{m}$ syringe filter (Sarstedt, Montreal, Quebec) in order to obtain cell-free supernatants.

\section{ELISA experiments}

Protein samples were prepared as follows: recombinant p60 protein was diluted with a coating buffer $\left(9 \mathrm{mM} \mathrm{N}_{2} \mathrm{CO}_{3}, 0.02 \mathrm{M}\right.$ $\mathrm{NaHCO}_{3}, 1 \mathrm{mM} \mathrm{NaN}, \mathrm{pH}$ 9.6) to obtain a concentration of 1.0 $\mu \mathrm{g} \mathrm{ml}^{-1}$. For bacterial samples, $50 \mu \mathrm{l}$ of cell-free supernatants from overnight cultures was diluted with $50 \mu \mathrm{l}$ of the coating buffer. The coating of the recombinant protein and supernatants was performed in microplates (LockWell, Maxisorp from Nunc) 
overnight at $4{ }^{\circ} \mathrm{C}(100 \mu \mathrm{l}$ per well). After coating, the plates were washed three times (10 min per washing) with a washing buffer (PBS (137 mM NaCl, $2.7 \mathrm{mM} \mathrm{KCl,} 10 \mathrm{mM} \mathrm{Na} \mathrm{HPO}_{4}, 2 \mathrm{mM}$ $\mathrm{KH}_{2} \mathrm{PO}_{4}, \mathrm{pH} 7.4$ ) containing $0.05 \%$ Tween 20 ) and blocked with $5 \%$ skimmed milk in PBS for 1 hour at $37^{\circ} \mathrm{C}$. The plates were sequentially incubated with the monoclonal IgG anti-p60 (18 $\mu \mathrm{g}$ $\mathrm{ml}^{-1}$ ) and then with a horseradish peroxidase (HRP) labelled secondary antibody (Biolynx Inc., Brockville, Ontario), diluted as directed by the supplier. Both antibodies were diluted with a diluting buffer (washing buffer containing 1\% skimmed milk). For colorimetric reaction, $100 \mu \mathrm{l}$ of the enzyme substrate 3,3',5,5'-tetramethylbenzidine (TMB) (Biolynx Inc., Brockville, Ontario) was added and the plates were incubated for 10 minutes at room temperature. Absorbance at $450 \mathrm{~nm}$ was measured using a microplate reader after the addition of $50 \mu \mathrm{l}$ of $2 \mathrm{M} \mathrm{H}_{2} \mathrm{SO}_{4}$. For all ELISA experiments, two negative controls were performed using a sample of BSA and fresh TSB culture media (data not shown). A second ELISA was done to validate the competition principle of the test. An amount of $0.1 \mu \mathrm{g}$ of recombinant p60 protein diluted in $100 \mu \mathrm{l}$ of the coating buffer was primarily coated in each well overnight at $4{ }^{\circ} \mathrm{C}$. After coating, the plates were washed three times (10 min per washing) with the washing buffer and blocked with 5\% skimmed milk in PBS for 1 hour at $37^{\circ} \mathrm{C}$. Monoclonal IgG anti-p60 $\left(18 \mu \mathrm{g} \mathrm{ml}^{-1}\right)$ was then added in each well and incubated for 1 hour at $37^{\circ} \mathrm{C}$. After another washing step, samples of $100 \mu$ of each cell-free supernatant from the different Listeria strains were incubated in wells for 15 minutes at room temperature. The assay was then finalized as described above with the secondary antibody and the TMB substrate.

\section{Western blot experiment}

Cell-free supernatants from overnight cultures $(4 \mathrm{ml})$ were concentrated by a factor of 66 after filtration through a $30 \mathrm{kDa}$ Amicon Ultra centrifugal filter unit (Millipore, Ontario, Canada), diluted 1:1 with the Laemmli sample buffer (Bio-Rad Laboratories, Ontario, Canada) and heated at $100{ }^{\circ} \mathrm{C}$ for 5 minutes. Protein separation was achieved by SDS-PAGE in $10 \%$ polyacrylamide gels. Transfer onto nitrocellulose membranes was performed overnight at $4{ }^{\circ} \mathrm{C}$. Membranes were blocked for 1 hour at room temperature under stirring in blocking buffer (PBS containing 5\% skimmed milk). After three washings with PBS $0.05 \%$ Tween 20 (10 min per washing under stirring), the membranes were incubated with monoclonal IgG anti-p60 $\left(0.4 \mu \mathrm{g} \mathrm{ml}^{-1}\right)$ for 1 hour at room temperature, washed three times as described above and then incubated with a horseradish peroxidase (HRP) labelled secondary antibody (Biolynx Inc.), diluted as directed by the supplier, for 1 hour at room temperature. The membranes were washed three times and then developed with the western blotting detection reagent Amersham ECL before being exposed to a photographic film (GE Healthcare Life Sciences, Québec, Canada). Recombinant P60 protein was used as a positive control.

\section{Labeling of monoclonal IgG}

A $0.5 \mathrm{ml}$ sample of monoclonal anti-p60 IgG in $50 \mathrm{mM}$ sodium borate buffer, pH $8.5\left(2.0 \mathrm{mg} \mathrm{ml}^{-1}\right)$ was labelled using a Dylight
550 Antibody labeling kit (Thermo Fisher Scientific Inc., IL, USA). The labeling was achieved according to the supplier instructions. The degree of labelling (DOL), as calculated from the absorbance values at $\lambda=280$ and $557 \mathrm{~nm}$ by applying a correction factor label absorption at $\lambda=280 \mathrm{~nm}$, was found to be 2.88 .

\section{Affinity column preparation}

The affinity column was obtained by conjugating the recombinant p60 protein with activated $\mathrm{CH}-$ Sepharose 4B (Sigma, Deisenhofen, Germany) as follows. One gram of dry resin powder was suspended in $200 \mathrm{ml}$ of cold $1 \mathrm{mM} \mathrm{HCl}$. The swollen resin was filtered in a polystyrene column (4 ml) (Bio-Rad Laboratories, Mississauga, Ont.) and washed with cold $1 \mathrm{mM} \mathrm{HCl}$. A $3 \mathrm{ml}$ sample of the p60 protein $\left(0.531 \mathrm{mg} \mathrm{ml}^{-1}\right)$ was dialysed in 1 litre of $0.1 \mathrm{M}$ sodium bicarbonate, $\mathrm{pH} 8.0$, containing $0.5 \mathrm{M} \mathrm{NaCl}$ overnight at $4{ }^{\circ} \mathrm{C}$ using a dialysis membrane of $3500 \mathrm{Da}$. Dialysed protein was mixed with the resin at $4{ }^{\circ} \mathrm{C}$ overnight under slow inversion. After the coating, excess active groups were blocked with $0.1 \mathrm{M}$ Tris- $\mathrm{HCl}$ buffer, $\mathrm{pH} 8.0$ for 1 hour. To remove the unbound protein, the resin was washed successively with cold $0.1 \mathrm{M}$ sodium bicarbonate $(30 \mathrm{ml}), 0.05 \mathrm{M}$ Tris- $\mathrm{HCl}, 0.5 \mathrm{M} \mathrm{NaCl}$, pH $8.0(30 \mathrm{ml}), 0.05 \mathrm{M}$ sodium acetate, $0.5 \mathrm{M} \mathrm{NaCl}, \mathrm{pH} 4.0(30 \mathrm{ml})$, PBS, pH $7.4(30 \mathrm{ml})$ and stored in PBS containing $0.05 \%$ sodium azide at $4{ }^{\circ} \mathrm{C}$. The stored column was then washed 5 times with PBS. A $0.5 \mathrm{ml}$ sample of labeled monoclonal $\mathrm{IgG}$ and $1.5 \mathrm{ml}$ of PBS were added to the resin and incubated overnight at $4{ }^{\circ} \mathrm{C}$ under inversion to fix the IgG on the recombinant p60 protein. The resin was washed with PBS until the fluorescence signal returned to the minimum level ( $\lambda=550 \mathrm{~nm}$ excitation, $\lambda=576 \mathrm{~nm}$ emission $)$.

\section{Detection of $L$. monocytogenes}

$1 \mathrm{ml}$ of the fresh culture of each bacterial strain was sub-cultured in $10 \mathrm{ml}$ of TSB for 18 hours at $37^{\circ} \mathrm{C}$ and successively diluted by serial dilutions with sterile physiological water $(0.85 \% \mathrm{NaCl}) .0 .1$ $\mathrm{ml}$ of each dilution was plated on trypticase soy agar (TSA, Difco Laboratory, Detroit, MI) in order to achieve a bacterial count. The right volume was calculated to obtain a theoretical amount of $1 \mathrm{CFU}$ that has been inoculated in $10 \mathrm{ml}$ of TSB for another 18 hours at $37^{\circ} \mathrm{C}$. The cell-free supernatant from this last 18 hours culture $(2 \mathrm{ml})$ was incubated with the resin for 10 minutes at room temperature under inversion. At the end of the incubation, $2 \mathrm{ml}$ of the flow-through containing the free p60-IgG-fluorophore complexes was harvested from the column. The fluorescence emission signal of this flow-through was measured at $\lambda_{\mathrm{em}}=576 \mathrm{~nm}$ with an excitation wavelength of $\lambda_{\mathrm{ex}}=550 \mathrm{~nm}$ and compared with the fluorescence signal of the background which corresponds to the residual fluorescence signal after the last wash of the column before the incubation with the bacterial sample. The column was then washed several times with PBS until the fluorescence signal returned to a minimum and constant level before being reused for another assay.

\section{Results and discussion}

\section{Western blot analysing with monoclonal IgG anti-p60}

The anti-p60 produced was tested to determine whether it was suitable for the specific detection of the L. monocytogenes $\mathrm{p} 60$ 


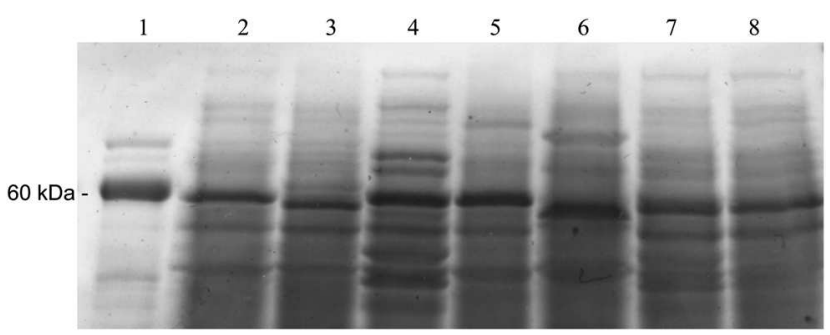

Fig. 1 Protein separation of concentrated cell-free supernatants from overnight cultures of various Listeria species by $10 \%$ SDS-PAGE electrophoresis. Lanes: 1 , recombinant p60 protein; 2, L. monocytogenes HPB 2569; 3, L. monocytogenes HPB 2558; 4, L. monocytogenes HPB 1043; 5, L. monocytogenes HPB 2812; 6, L. monocytogenes HPB 2739; 7 , L. monocytogenes HPB 2371; 8, L. innocua.

protein. For this purpose, a Western blot analysis with the supernatant proteins of various Listeria strains was performed. The six strains of L. monocytogenes used for the experiment belong to two of the three serotypes responsible for up to $96 \%$ of the cases of human listeriosis. ${ }^{41}$ L. innocua was used as nonpathogenic Listeria species. The protein pattern of the culture supernatants obtained by SDS-PAGE is shown in Fig. 1. A 60 $\mathrm{kDa}$ protein band is clearly visible for each of the strains which correspond to the protein p60 or the p60-related protein of $L$. innocua. ${ }^{38}$ The important background on the gel and the large amount of protein bands are due to the fact that supernatants concentrated by a factor of 66 were used to reach a sufficient concentration of the $\mathrm{p} 60$ protein that allowing its visualization on the gel. As shown in Fig. 2, the monoclonal anti-p60 reacted specifically with the p60 protein of $L$. monocytogenes whereas no cross reactivity with the p60-related protein of $L$. innocua could be observed. These results are consistent with those obtained by Bubert et al. (1992). It can be assumed, based on the results, that the monoclonal antibody used in this study, raised against the same PepD, is highly specific and can recognise all of the 13 serotypes of L. monocytogenes evaluated in this study.

\section{Detection of the native p60 protein in supernatants by ELISA}

While the Western blot analysis allows verifying the recognition of denatured proteins by antibodies, an ELISA test performed with fresh supernatants allows verifying the recognition of native proteins. The possibility that the epitope is inaccessible when the

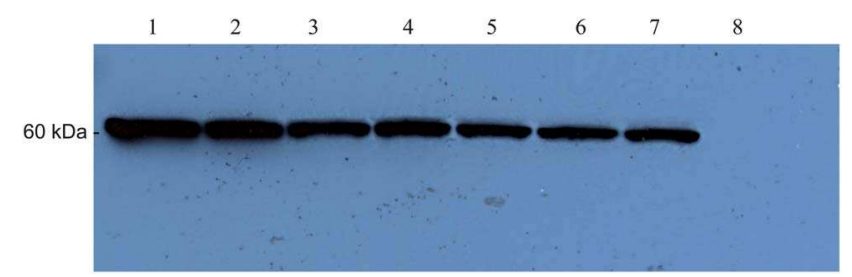

Fig. 2 Western blot analysis of concentrated cell-free supernatants from overnight cultures of various Listeria species using a monoclonal anti-p60 antibody. Lanes: 1 , recombinant $\mathrm{p} 60$ protein; 2, L. monocytogenes HPB 2569; 3, L. monocytogenes HPB 2558; 4, L. monocytogenes HPB 1043; 5, L. monocytogenes HPB 2812; 6, L. monocytogenes HPB 2739; 7, L. monocytogenes HPB 2371; 8, L. innocua.
Table 1 Reactivity of the monoclonal anti-p60 with supernatants from different Listeria strains by direct ELISA

\begin{tabular}{ll}
\hline Organism & Optical density \\
\hline $\begin{array}{l}\text { Listeria innocua } \\
\text { Listeria monocytogenes }\end{array}$ & 0.088 \\
HPB 2812 & 1.022 \\
HPB 1043 & 0.961 \\
HPB 2569 & 1.123 \\
HPB 2558 & 0.962 \\
HPB 2739 & 1.113 \\
HPB 2371 & 0.865 \\
\hline
\end{tabular}

protein is in its native form cannot be excluded. Therefore, it is important to perform both of these tests in order to confirm the detection of the epitope in the native and denatured form. Direct ELISA tests were performed with fresh cell-free culture supernatants of the different strains of Listeria. Since ELISA is more sensitive than the Western blot, it was achieved with nonconcentrated supernatants. Results are shown in Table 1 and it can be seen that the monoclonal anti-p60 recognized all the $L$. monocytogenes strains tested while it presented no cross-reaction with the supernatant of non-pathogenic L. innocua. The recombinant $\mathrm{p} 60$ protein was used as a positive control, and fresh TSB broth alone, used as a negative control, did not show any reaction (data not shown).

\section{Validation of the principle of the test by ELISA}

The detection test is based on a principle of competition between the recombinant p60 protein, to which the labeled monoclonal anti-p60 is fixed in the column, and the p60 protein secreted by bacterial strains. The determinant factor that underpins the success of the test is the ability of these fixed antibodies of being naturally displaced by competition on the free $\mathrm{p} 60$ protein from the bacterial culture sample after its injection into the column. The amount of antibodies transferred depends on the concentration of the free p60 protein. The new antibody-free p60 protein complexes can be harvested at the end of the column and the fluorescence rate is measured. In order to verify whether the antibodies can be transferred, a competition ELISA has been designed to recreate what happens in the column. However, it is not a classical competition ELISA since both of the antigens were not added at the same time. First, $0.1 \mu \mathrm{g}$ of the recombinant p60 protein was coated in each well on which a certain amount of antibodies was then fixed. A volume of the supernatant from the Listeria culture was added to each well and incubated for 15 minutes at room temperature to allow the antibodies to get transferred on the free $\mathrm{p} 60$ protein from supernatants. These new antibody-free p60 protein complexes were washed and the lost in the initial amount of antibodies is revealed by a diminution of the optical density after the reaction with a secondary antibody. The results of this competition ELISA show that supernatants obtained from $L$. monocytogenes cultures can dislodge antibodies from their initial position while the supernatant from $L$. innocua cannot (Table 2). It means that the antibodies recognise only the p60 protein in the supernatant of the L. monocytogenes strains and that this protein can capture a certain amount of antibodies already fixed on the recombinant p60 protein. The same 
Table 2 Non-classical competition ELISA ${ }^{a}$ designed to visualise the displacement of the monoclonal anti-p60 from the immobilized recombinant $\mathrm{p} 60$ protein to the free $\mathrm{p} 60$ protein from supernatants

\begin{tabular}{lc}
\hline Supernatant added & Optical density \\
\hline None & 1.239 \\
Recombinant p60 $(0.1 \mu \mathrm{g})$ & 0.623 \\
L. innocua & 1.241 \\
L. innocua diluted & 1.229 \\
L. monocytogenes & \\
HPB 2812 & 0.661 \\
HPB 2812 diluted & 0.996 \\
HPB 1043 & 0.593 \\
HPB 1043 diluted & 0.983 \\
HPB 2569 & 0.701 \\
HPB 2569 diluted & 1.086 \\
HPB 2558 & 0.638 \\
HPB 2558 diluted & 1.018 \\
HPB 2739 & 0.777 \\
HPB 2739 diluted & 1.070 \\
HPB 2371 & 0.663 \\
HPB 2371 diluted & 1.069 \\
& \\
&
\end{tabular}

experiment was also performed with supernatants diluted to half to see if the diminution of the optical density would be less important. This is indeed what has been observed and all these results confirm that the competition principle can be applied in the column for the detection test.

\section{Detection of L. monocytogenes}

The preparation of the column was carried out by fixing the labeled monoclonal anti-p60 to the recombinant p60 protein, which is immobilized on a Sepharose 4B matrix. The detection of the bacteria is possible due to the displacement of the labeled monoclonal anti-p60 by the p60 protein secreted by L. monocytogenes. Displaced fluorescent antibodies are measured by fluorescence emission of the eluate and represent a measure of the amount of free p60 protein in the supernatant and thus, if the initial sample was contaminated by L. monocytogenes. Before testing any sample, the column was washed several times with a neutral buffer until the fluorescence signal of the eluate was minimal and constant. This signal was considered as the background. A volume $(2 \mathrm{ml})$ of cell-free supernatants from an 18 hour culture inoculated with a theoretical amount of $1 \mathrm{CFU}$ was added to the column and incubated for 10 minutes at room temperature. A $2 \mathrm{ml}$ eluate fraction was collected and the fluorescence emission was measured and compared with the background signal. A significant increase in the fluorescence signal means that $L$. monocytogenes was present in the initial sample. The increase of fluorescence signal for each bacterial strain is shown in Fig. 3. For each strain of L. monocytogenes tested, a significant increase in fluorescence emission was observed compared to the background whereas the signal for L. innocua remained constant.

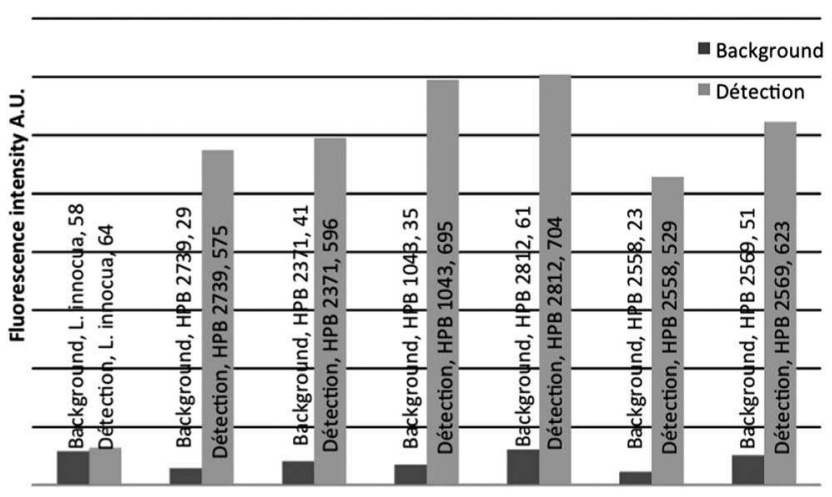

Fig. 3 Fluorescence immunoassay for detection of $L$. monocytogenes. Fluorescence emission was recorded at $\lambda_{\mathrm{em}}=576 \mathrm{~nm}$ and is a representative of the labeled antibody eluted from the column after incubation with cell-free supernatants from overnight cultures of various Listeria species. Background signals represent the minimal and constant fluorescence emission after several washes. Excitation wavelength was at $\lambda_{\mathrm{ex}}=550 \mathrm{~nm}$.

\section{Conclusions}

In conclusion, a monoclonal antibody has been produced using a small 11 amino acid peptide of which the sequence is highly conserved in the protein p60 of L. monocytogenes. Our results showed that this antibody is very specific to the p60 protein of $L$. monocytogenes and presents no cross-reactivity with the p60related protein of non-pathogenic Listeria species. This antibody was successfully used in the conception of a competitive fluorescent immunoassay for the detection of $L$. monocytogenes. The method consisted of the fixation of the labeled monoclonal antip60 on a recombinant p60 protein, which is immobilized on a Sepharose 4B matrix. The addition of a cell-free supernatant from a bacterial culture containing the secreted p60 protein induces the displacement of the antibody, which results in an increase in the fluorescence signal of the eluate at the emission wavelength of the fluorophore. The assay allowed the detection of the 6 strains of L. monocytogenes tested after only 18 hours of incubation with a theoretical initial inoculum of $1 \mathrm{CFU}$. No false positive with $L$. innocua was observed and thus, this assay represents a promising way to develop a sensitive, specific and rapid detection test not only for $L$. monocytogenes, but also for many other pathogens. Other experiments are in progress for the optimisation of the test and also for the establishment of a standardized procedure applicable in the industry.

\section{Acknowledgements}

This research was supported by the Ministry of Economic Development, Innovation and Export Trade, International Program (MDEIE). S. Beauchamp was also supported by a fellowship from Nature Research and Technology: International Training Program. The project was also partially funded by the CNR project "Conoscenze integrate per sostenibilità e innovazione del Made in Italy agroalimentare (CISIA)" to A.P. and S.D.

\section{References}

1 M. Gandhi and M. L. Chikindas, Int. J. Food Microbiol., 2007, 113, $1-15$. 
2 B. Carpentier and O. Cerf, Int. J. Food Microbiol., 2011, 145, 1-8.

3 T. Møretrø and S. Langsrud, Biofilms, 2004, 1, 107-121.

4 S. D. Ha, S. Y. Park, J. W. Choi, J. Yeon and M. J. Lee, et al., J. Microbiol. Biotechnol., 2005, 15, 1323-1329.

5 C. W. Donnelly, Nutr. Rev., 2009, 59, 183-194.

6 P. D. MacDonald, R. E. Whitwam, J. D. Boggs, J. W. Reardon and R. R. Saah, et al., Clin. Infect. Dis., 2001, 33, 1236.

7 S. J. Olsen, M. C. Evans, S. Hunter, V. Reddy and L. Kornstein, et al., Clin. Infect. Dis., 2001, 33, 1237.

8 K. C. Klontz, S. Wong, D. Street and S. I. Delgado, J. Food Prot., 2000, 63, 1113-1116.

9 E. C. D. Todd and S. Notermans, Food Control, 2011, 22, 1484 1490.

10 B. Swaminathan and P. Gerner-Smidt, Microbes Infect., 2007, 9, $1236-1243$.

11 M. Magnani, G. Amagliani, G. Brandi, E. Omiccioli and A. Casiere, et al., Food Microbiol., 2004, 21, 597-603.

12 D. H. Chung, W. B. Shim, J. G. Choi, J. Y. Kim and Z. Y. Yang, et al., J. Microbiol. Biotechnol., 2007, 17, 1152-1161.

13 V. Velusamy, K. Arshak, O. Korostynska, K. Oliwa and C. Adley, Biotechnol. Adv., 2010, 28, 232-254.

14 M. Zunabovic, K. J. Domig and W. Kneifel, LWT-Food Sci. Technol., 2011, 44, 351-362.

15 D. Y. Hao, L. R. Beuchat and R. E. Brackett, Appl. Environ. Microbiol., 1987, 53, 955-957.

16 D. McClain and W. H. Lee, J. - Assoc. Off. Anal. Chem., 1988, 71 660-664.

17 S. B. Barbuddhe, V. S. Parihar, M. L. Danielsson-Thm and W. Tham, Food Control, 2008, 19, 566-569.

18 M. Drake, J. Isonhood and L. A. Jaykus, Food Microbiol., 2006, 23, 584-590.

19 K. Balakrishna, H. S. Murali and H. V. Batra, J. Food Saf., 2010, 30, 263-275.

20 Z. G. Li, W. Chen, Y. W. Yang and W. Deng, J. Food, Agric Environ., 2010, 8, 96-99.

21 M. C. Simon, D. I. Gray and N. Cook, Appl. Environ. Microbiol., 1996, 62, 822-824
22 P. G. Lantz, B. Hahn-Hägerdal and P. Rådström, Trends Food Sci. Technol., 1994, 5, 384-389.

23 A. Agersborg, R. Dahl and I. Martinez, Int. J. Food Microbiol., 1997, 35, 275-280.

24 S. S. Iqbal, M. W. Mayo, J. G. Bruno, B. V. Bronk and C. A. Batt, et al., Biosens. Bioelectron., 2000, 15, 549-578.

25 C. S. Chen and R. A. Durst, Talanta, 2006, 69, 232-238.

26 R. L. Churchill, H. Lee and J. C. Hall, J. Microbiol. Methods, 2006, 64, 141-170.

27 V. Gangar, M. S. Curiale, A. D’Onorio, A. Schultz and R. L. Johnson, et al., J. AOAC Int., 2000, 83, 903-918.

$28 \mathrm{~K}$. Hibi, A. Abe, E. Ohashi, K. Mitsubayashi and H. Ushio, et al., Anal. Chim. Acta, 2006, 573-574, 158-163.

29 J. A. Hudson, R. J. Lake, M. G. Savill, P. Scholes and R. E. McCormick, J. Appl. Microbiol., 2001, 90, 614-621.

30 Y. S. Jung, J. F. Frank and R. E. Brackett, J. Food Prot., 2003, 66, $1283-1287$.

31 K. Y. Yu, Y. Noh, M. Chung, H. J. Park and N. Lee, et al., Clin. Diagn. Lab. Immunol., 2004, 11, 446-451.

32 M. Magliulo, P. Simoni, M. Guardigli, E. Michelini and M. Luciani, et al., J. Agric. Food Chem., 2007, 55, 4933-4939.

33 A. M. Sewell, D. W. Warburton, A. Boville, E. F. Daley and K. Mullen, Int. J. Food Microbiol., 2003, 81, 123-129.

34 W. B. Shim, J. G. Choi, J. Y. Kim, Z. Y. Yang and K. H. Lee, et al., J. Microbiol. Biotechnol., 2007, 17, 1152-1161.

35 P. Leonard, S. Hearty, J. Brennan, L. Dunne and J. Quinn, et al., Enzyme Microb. Technol., 2003, 32, 3-13.

36 A. Bubert, M. Kuhn, W. Goebel and S. Kohler, J. Bacteriol., 1992, 174, 8166-8171.

37 M. Kuhn and W. Goebel, Infect. Immun., 1989, 57, 55-61.

38 A. Bubert, P. Schubert, S. Kohler, R. Frank and W. Goebel, Appl. Environ. Microbiol., 1994, 60, 3120-3127.

39 A. Bubert, S. Kohler and W. Goebel, Appl. Environ. Microbiol., 1992, 58, 2625-2632.

40 S. Hearty, P. Leonard, J. Quinn and R. O'Kennedy, J. Microbiol. Methods, 2006, 66, 294-312.

41 R. B. Tompkin, J. Food Prot., 2002, 65, 709-725. 